DOI: https://doi.org/10.24144/2409-6857.2018.2(52).186-193

УДК 369.542:368.911.12:364.35

Похилько С.В., Зайцев О.В., Миргородська В.С.

\title{
ЗАБЕЗПЕЧЕННЯ АДЕКВАТНОСТІ ПЕНСІЙНИХ ВИПЛАТ ЗА УМОВИ ФУНКЦІОНУВАННЯ ТРИРІВНЕВОЇ ПЕНСІЙНОЇ СИСТЕМИ
}

\begin{abstract}
У статті розглянуто питання ефективності функціонування трирівневої структури у забезпеченні стабільності пенсійної системи і адекватності пенсійних виплат у довгостроковій перспективі. Узагальнено класифікацію показників оцінки адекватності і стабільності пенсійної системи, які дозволяють розрахувати достатні для задоволення потреб громадян похилого віку пенсійні виплати. Проаналізовано стійкість пенсійних систем та фактори впливу на неї. Досліджено можливість використання коефіцієнта заміщення пенсією втраченого заробітку для розрахунку адекватного розміру пенсіі.
\end{abstract}

Ключові слова: пенсійна система, адекватність, стабільність, коефіиієнт заміщення, пенсійні виплати

Постановка проблеми. Головною метою економічного розвитку соціально-орієтованої держави $є$ підтримання достатнього рівня життя незахищених верств населення. Кожен четвертий громадянин Європейського союзу та України залежить від своїх пенсійних доходів. Молодші громадяни у майбутньому також очікують на отримання пенсії і мають безпосередній інтерес у забезпеченні свого пенсійного майбутнього на достаньому рівні. Робітники сплачують податки і внески на власне соціальне забезпечення для себе та на допомогу нинішнім пенсіонерам. Втім розподільча система $\epsilon$ неефективною для скорочення видатків та зниження навантаження на бюджет у випадку несприятливих демографічних змін. Задля підтримання стабільності національної пенсійної системи України у довгостроковій перспективі активному реформуванню мають підлягати усі три рівні кожної $з$ неї.

Аналіз останніх досліджень і публікацій. Різнобічні вектори державної соціальної політики у сфері пенсійного забезпечення висвітлені в працях таких українських учених: Загорєєва О.Ю. [2], Філіпчук П.В. [11] Серед зарубіжних науковців аналіз пенсійних систем у контексті достатності та адекватності проводили Роик В.Д. [1], Хить Л.В. [6], Holzmann R., Hinz R. [8],

(C) Похилько Світлана Василівна, к.е.н., доцент кафедри фінансів і підприємництва, Сумський державний університет, м. Суми, тел. +380542335383, email: s.pokhylko@finance.sumdu.edu.ua

Зайцев Олександр Васильович, к.е.н., доцент кафедри фінансів і підприємництва, Сумський державний університет, м. Суми, тел. +380542335383, email: o.zaitsev@finance.sumdu.edu.ua

Миргородська Вікторія Сергіївна, магістрант кафедри фінансів і підприємництва, Сумський державний університет, м. Суми, тел. +380542335383, email: vict.mirgorod@gmail.com
Соловьев А.К. [9].

Незважаючи на значну кількість публікацій стосовно доцільності створення умов для повноцінного функціонування трирівневої пенсійної системи в Україні, у сучасній науці ще не було повністю розкрито сутність і досліджено повноту дотримання принципу адекватності пенсійних виплат для задоволення потреб громадян пенсійного віку, потребує узагальнення класифікація показників вимірювання адекватності пенсійних виплат та стабільності пенсійної системи.

Формулювання цілей статті. Цілями статті $\epsilon$ розкриття сутності поняття «адекватність пенсійних виплат»; узагальнення класифікації вимірників адекватності пенсійних виплат та показників оцінки стабільності пенсійних систем; оцінка стабільності та адекватності трирівневих пенсійних систем країн ЄС для запровадження пенсійної системи даного типу в Україні; обгрунтування використання коефіцієнту заміщення заробітної плати для розрахунку достатніх для забезпечення потреб пенсійних виплат.

Опис основного матеріалу дослідження. Забезпечення життедіяльності громадян пенсійного віку пов'язане 3 пошуком державою джерел доходів іiі фінансування. В основі сучасних національних пенсійних систем, у тому числі й в український, лежить поєднання наступних двох принципів побудови: перший передбачає необхідність забезпечення мінімальних гарантій рівня пенсійного доходу для всіх включених до системи (боротьба 3 бідністю), другий - розглядає пенсії як резервовану частину заробітної плати, покликану гарантувати застрахованому працівнику збереження доходу, порівняного $з$ його рівнем до настання пенсії [1]. Тобто двоїста економічна природа i двоїста функція пенсій дозволяє 
виконувати їх головне призначення - надання соціального захисту непрацездатним громадянам за допомогою встановлення адекватного рівня пенсійного забезпечення. Пенсія - систематичні виплати громадянам пенсійного віку для забезпечення їх життєдіяльності, які проводяться за рахунок раніше внесених ними пенсійних страхових внесків до державних та недержавних пенсійних фондів [2].

Основні цілі, на досягнення яких спрямована діяльність системи пенсійного забезпечення, були закріплені в базових конвенціях і рекомендаціях Міжнародної організації праці, а в подальшому підтверджені i розвинені в Європейському кодексі соціального забезпечення (1964 року, переглянутий в 1996 p) i в Свропейській соціальній хартії.

За статтею 23 Європейської соціальної хартії «Право осіб похилого віку на соціальний захист» держави-учасниці, однією з яких є Україна, мають надавати пенсіонерам достатньо коштів для «продовження життя на задовільному рівні і активної участі в державному, громадському і культурному житті». Для цього рівень пенсійного доходу повинен забезпечити не просто реалізацію мінімальних потреб, а й адекватний рівень заміщення пенсією заробітної плати, достатній для звичного матеріального забезпечення $\mathrm{i}$ підтримки колишнього соціального статусу сім'ї пенсіонера. Громадяни розвинених країн після припинення трудової діяльності за умови достатнього страхового стажу можуть розраховувати на достатній рівень пенсій. Зазначене $\epsilon$ можливим лише за умов довгостроковоорієнтованої державної політики на забезпечення стійкості та адекватності пенсійних систем та постійного їх моніторингу в умовах підвищення тривалості життя та скорочення народжуваності, наслідком чого $\epsilon$ старіння населення.

Як показано на рис. 1, серед країн СС зростає чисельність представників вікової групи громадян старших за 65 років, в той час як кількість представників вікової групи 15-64 років постійно скорочується. В Україні також спостерігається дана тенденція [3]. Отже, співвідношення між загальною кількістю людей літнього віку, які є економічно неактивними (у віці 65 років і старіше) і кількістю осіб працездатного віку (від 15 до 64) зберігається на рівні $17-19 \%$, у той час як в Україні даний показник становить $67 \%$.

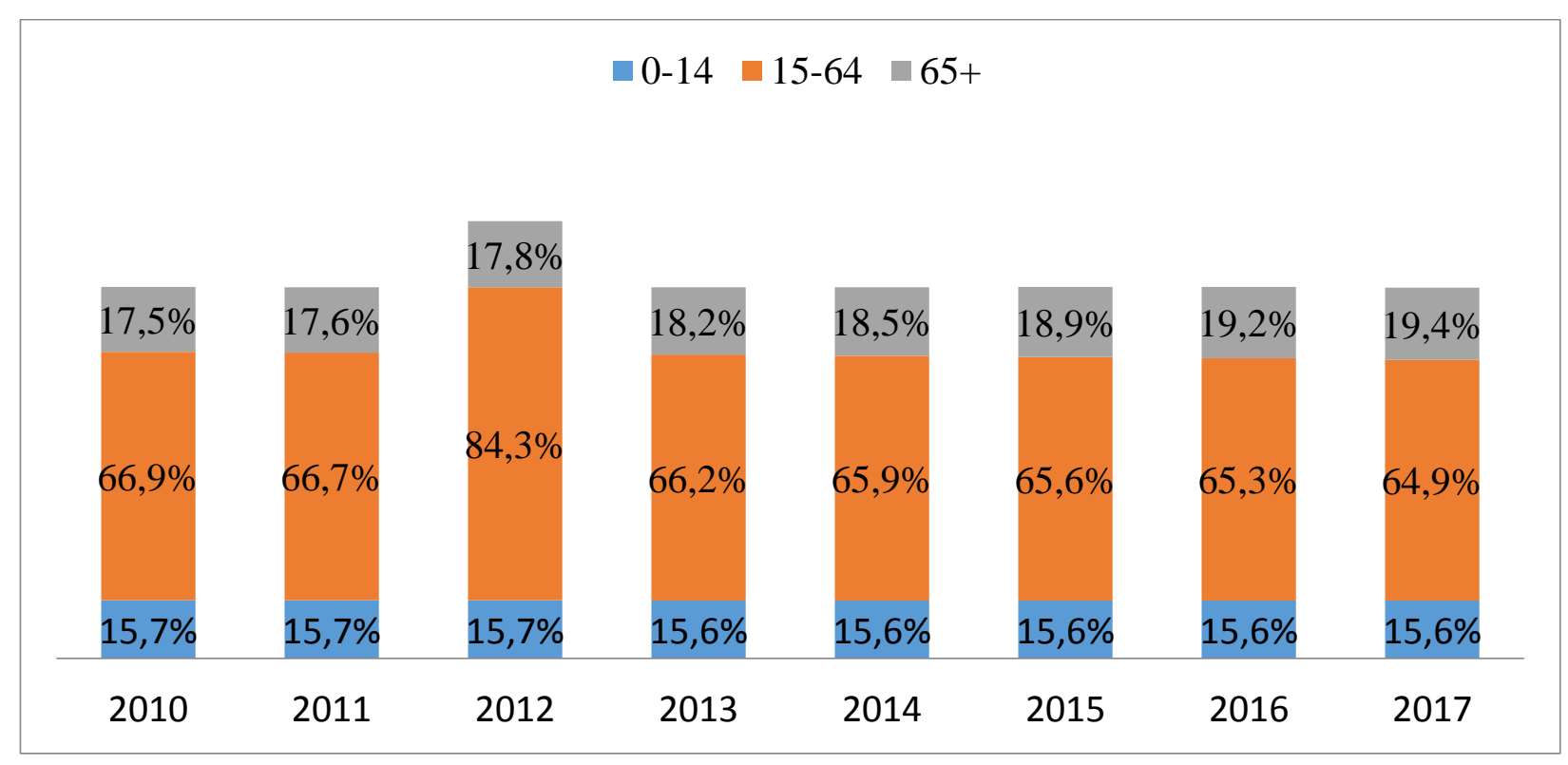

Рис. 1. Вікова структура населення у країнах СС-28, 2010-2017 роки*

*Складено авторами за матеріалами [4]

Зазначена вікова структура населення країн ЄС та України свідчить про регресивний тип відтворення поколінь. Відбувається постійне скорочення економічно ефективної частини населення, що призводить до ще більшого зростання рівня податкового навантаження на населення працездатного віку.
Стійкість пенсійної системи пов'язана 3 фіскальним і фінансовим балансом між доходами i податковим навантаженням (взаємодії працівників-вкладників і пенсіонерів-бенефіціарів). Для підтримання стійкості в довгостроковій перспективі державні пенсійні схеми повинні бути в змозі не зважати на 
несприятливі демографічні процеси, зокрема старіння населення та уникнути дестабілізації державних фінансової системи.

Для оцінки стійкості систем пенсійного забезпечення може бути використана низка індикаторів, кожен $з$ якої відображає конкретний аспект проблеми:

1. Макроекономічні показники базуються на оцінці доходів і витрат системи пенсійного забезпечення. Вони прогнозуються за найбільш ймовірними демографічними та економічними сценаріями, виходячи з гіпотези про сталість основних податків на заробітну плату, виплачуваних працездатним населенням, i про середню пенсійну виплату. До них відносять: відношення пенсійних витрат до ВВП; оптимальну ставку податку; індекс охоплення; відношення дефіциту державного бюджету до ВВП.
2. Мікроекономічні показники акцентують увагу на індивідуальному рівні і повному обліку нерівноцінності внесків кожного 3 працівників і його доходів протягом життя. Одним 3 таких показників $є$ коефіцієнт поточної вартості, який являє собою відношення між поточною вартістю одержуваних пенсійних виплат i поточною вартістю вирахуваних із заробітної плати податків, утриманих на пенсійне забезпечення.

До системи комплексної оцінки ефективності та фінансової стійкості розподільчонакопичувальної пенсійної системи входять показники, що дозволяють всебічно оцінювати ефективність та фінансову стійкість пенсійної системи в умовах як накопичувального, так i розподільчого методу фінансування (табл.1) [6].

Також варто звернути увагу на інтегральний показник стійкості національних пенсійних

\section{Показники комплексної оцінки ефективності та фінансової стійкості розподільчо- накопичувальної пенсійної системи*}

\begin{tabular}{|c|c|c|c|}
\hline $\begin{array}{l}\text { Показники оцінки } \\
\text { рівня зрілості } \\
\text { пенсійної системи }\end{array}$ & $\begin{array}{c}\text { Показники оцінки } \\
\text { рівня пенсійних } \\
\text { виплат }\end{array}$ & $\begin{array}{c}\text { Відносні вартісні } \\
\text { показники ефективності } \\
\text { функціонування } \\
\text { пенсійних систем }\end{array}$ & $\begin{array}{c}\text { Показники фінансової стійкості } \\
\text { пенсійних систем }\end{array}$ \\
\hline $\begin{array}{l}\text { - коефіцієнт } \\
\text { підтримки } \\
\text { пенсійних систем; } \\
\text { - коефіцієнт } \\
\text { економічної } \\
\text { залежності }\end{array}$ & $\begin{array}{l}\text { - коефіцієнт рівня } \\
\text { життя пенсіонерів; } \\
\text { - коефіцієнт } \\
\text { заміщення; } \\
\text { - коефіцієнт } \\
\text { охоплення; } \\
\text { - частка фонду } \\
\text { оплати праці у } \\
\text { ВВП }\end{array}$ & $\begin{array}{l}\text { - внутрішньосистемна } \\
\text { вартість; } \\
\text { - національна вартість } \\
\text { пенсійної системи; } \\
\text { - рентабельність } \\
\text { пенсійних накопичень; } \\
\text { - рентабельність } \\
\text { інвестованих пенсійних } \\
\text { резервів }\end{array}$ & $\begin{array}{l}\text { - коефіцієнт фінансової стійкості } \\
\text { державного пенсійного фонду; } \\
\text { - коефіцієнт фінансової стійкості } \\
\text { недержавного пенсійного фонду; } \\
\text { - інтегральний показник фінансової } \\
\text { стійкості розподільчо-накопичувальної } \\
\text { пенсійної системи; } \\
\text { - абсолютний показник фінансової } \\
\text { стійкості розподільно-накопичувальної } \\
\text { ПС (показник дефіциту/профіциту) }\end{array}$ \\
\hline
\end{tabular}

*Складено авторами за матеріалами [6]

систем - індекс стійкості пенсійної системи (Pension Sustainability Index - PSI), який враховує демографічну ситуацію,видатки державного бюд- жету на пенсійне забезпечення і будову пенсійної системи для систематичного виміру довгострокової стійкості у пенсійній системі (табл. 2).

Фактори, що враховус індекс стійкості пенсійної системи*

Таблиця 2

\begin{tabular}{|c|c|c|}
\hline Демографічна ситуація & Державні фінанси & Будова пенсійної системи \\
\hline $\begin{array}{l}\text { 1) коефіцієнт демографічного } \\
\text { навантаження - це співвідношення } \\
\text { чисельності } \\
\text { непрацездатному віб } \\
\text { пенсійного зрости або ще не } \\
\text { вступили в працездатний вік) до } \\
\text { чисельності } \\
\text { працездатному віці; } \\
\text { 2) готовність до помірних змін } \\
\text { у співвідношенні «робота-вихід на } \\
\text { пенсію» }\end{array}$ & $\begin{array}{l}\text { 1) рівень державних видатків } \\
\text { на пенсійне забезпечення; } \\
\text { 2) достатність державних } \\
\text { ресурсів у разі збільшення } \\
\text { економічного тягара у результаті } \\
\text { зростання пенсійних видатків. }\end{array}$ & $\begin{array}{l}\text { 1) держава забезпечує } \\
\text { мінімальний прожитковий рівень } \\
\text { для усіх громадян; } \\
\text { 2) високий пенсійний вік або } \\
\text { пенсійний вік, пов'язаний із } \\
\text { тривалістю життя; } \\
\text { 3) наявність інших джерел } \\
\text { фінансування пенсій, окрім } \\
\text { державних. }\end{array}$ \\
\hline
\end{tabular}


Проведена оцінка національних пенсійних систем країн ЄС за цим показником (табл. 3) показала, що найвищий індекс стійкості мають Данія, Естонія, Великобританія, Фінляндія,
Австрія та Бельгія, що пов'язано з підвищенням віку виходу на пенсію та прогнозом щодо зменшення витрат на пенсійне забезпечення [7].

Таблиця 3

Рейтинг країн ЄС за індексом стійкості пенсійної систем у 2016 р. [7]

\begin{tabular}{|c|c|c|c|c|}
\hline Країна & $\begin{array}{c}\text { Демографічна } \\
\text { ситуація }\end{array}$ & Державні фінанси & $\begin{array}{c}\text { Будова пенсійної } \\
\text { системи }\end{array}$ & Разом \\
\hline Данія & 7,40 & 7,30 & 8,53 & 7,93 \\
\hline Естонія & 7,00 & 8,20 & 6,95 & 7,28 \\
\hline Великобританія & 7,40 & 6,40 & 7,50 & 7,20 \\
\hline Фінляндія & 7,00 & 5,60 & 7,60 & 6,93 \\
\hline Австрія & 6,60 & 5,20 & 7,00 & 6,46 \\
\hline Болгарія & 6,60 & 6,60 & 6,30 & 6,43 \\
\hline Румунія & 6,40 & 6,70 & 6,35 & 6,43 \\
\hline Угорщина & 7,20 & 5,70 & 6,15 & 6,30 \\
\hline Франція & 7,00 & 4,90 & 6,60 & 6,28 \\
\hline Хорватія & 6,20 & 6,10 & 6,15 & 6,13 \\
\hline Іспанія & 4,60 & 5,50 & 6,60 & 5,83 \\
\hline Італія & 4,80 & 3,70 & 7,10 & 5,68 \\
\hline Словенія & 5,20 & 4,70 & 6,00 & 5,46 \\
\hline
\end{tabular}

Адекватність пенсій визначається їх здатністю запобігати бідності, ступенем, за яким вони відповідають рівню передпенсійного доходу і як вони співвідносяться 3 середніми доходами громадян, вік яких є нижчим за пенсійний. Одні країни визначають адекватність як соціальний стандарт такий, як межа бідності або відсоток від доходу до настання пенсійного віку, в інших державах це поняття передбачає підтримку певного рівня життя [5].

За визначенням Світового банку адекватною $\epsilon$ система, що забезпечує достатній рівень доходу для запобігання бідності у старості (на рівні конкретної країни, охоплюючи усе непрацездатне населення, разом з тим створює умови для рівномірного споживання протягом усього пенсійного життя для переважної більшості населення, враховуючи рівень доходу до виходу на пенсію і їхні потреби [8].

Вимірювання пенсійної адекватності $\epsilon$ складним завданням, і має низку показників. Вони включають в себе пенсійний дохід від усіх трьох пенсійних рівнів, інші джерела доходу i оцінку добробуту літніх людей (наприклад робота, житло), податковий режим i доступ пенсіонерів до послуг і товарів в натуральній формі, що надаються державами. Однак в Україні накопичувальний рівень запроваджений лише формально.

У СС було запропоновано показники вимірювання адекватності пенсій $з$ урахуванням рівня життя населення, соціальної справедливості та зайнятості (табл.4). Міжнародна організація праці рекомендує країнам будувати свої пенсійні системи не на основі прожиткового мінімуму, а саме на основі коефіцієнта заміщення пенсією втраченого заробітку, оскільки саме він $\epsilon$ показником ефективності пенсійної системи країни. Економічний зміст даного показника полягає в оцінці ступеня заміщення пенсією заробітної плати, раніше одержуваної працівником. Існують різні підходи до його розрахунку, зокрема розрахунок співвідношення середньої пенсії і середньої заробітної плати або оцінка співвідношення пенсії $\mathrm{i}$ середнього заробітку конкретного пенсіонера. Нормативне значення показника повинно бути не нижче $40 \%$ [9]. 
Таблиця 4

Показники вимірювання адекватності пенсій*

\begin{tabular}{|c|c|c|c|c|}
\hline Бідність & $\begin{array}{c}\text { Проблема } \\
\text { зайнятості, } \\
\text { пов’язана з } \\
\text { виходом на } \\
\text { пенсію }\end{array}$ & $\begin{array}{c}\text { Доходи, які отримують } \\
\text { нинішні пенсіонери }\end{array}$ & $\begin{array}{c}\text { Доходи майбутніх } \\
\text { пенсіонерів }\end{array}$ & Нерівність \\
\hline $\begin{array}{l}\text { - людей віком } \\
\text { старше за } 65 \\
\text { років, схильні до } \\
\text { ризику бідності } \\
\text { (нижче } 60 \% \text { від } \\
\text { середнього } \\
\text { доходу); } \\
\text { - частка людей, } \\
\text { що потерпають } \\
\text { від важких мате- } \\
\text { ріальних неста- } \\
\text { тків. }\end{array}$ & $\begin{array}{l}\text { - } \text { рівень зай- } \\
\text { нятості людей } \\
\text { пенсійного віку; } \\
\text { - середня трива- } \\
\text { лість робочого } \\
\text { життя. }\end{array}$ & $\begin{array}{l}\text { - співввідношення від- } \\
\text { носних середніх доходів; } \\
\text { - сукупний коефіцієнт } \\
\text { заміщення; } \\
\text { - коефіцієнт теоретичного } \\
\text { заміщення (рівень пен- } \\
\text { сійного доходу в перший } \\
\text { рік після виходу на пенсію } \\
\text { у відсотках від ін- } \\
\text { дивідуального заробітку } \\
\text { на момент отримання } \\
\text { пенсій). }\end{array}$ & $\begin{array}{l}\text { - передбачуваний } \\
\text { коефіцієнт теоре- } \\
\text { тичного заміщення; } \\
\text {-поточний і прог- } \\
\text { нозований коефі- } \\
\text { цієнт допомог; } \\
\text { - поточний i } \\
\text { прогнозований } \\
\text { середній показник } \\
\text { заміщення. }\end{array}$ & $\begin{array}{l}\text { - гендерний роз- } \\
\text { рив у пенсійних } \\
\text { доходах (\%, за } \\
\text { яким } \quad \text { середня } \\
\text { пенсія жінок } \\
\text { нижче, ніж у } \\
\text { чоловіків); } \\
\text { - нерівність у } \\
\text { розподілі доходів } \\
\text { (індикатор 80/20). }\end{array}$ \\
\hline
\end{tabular}

*Складено авторами за матеріалами [7]

На погляд авторів, зазначений показник $є$ середнього рівня індивідуальних виплат i недосконалим для розрахунку пенсійних виплат, середнього індивідуального заробітку. оскільки характеризує співвідношення

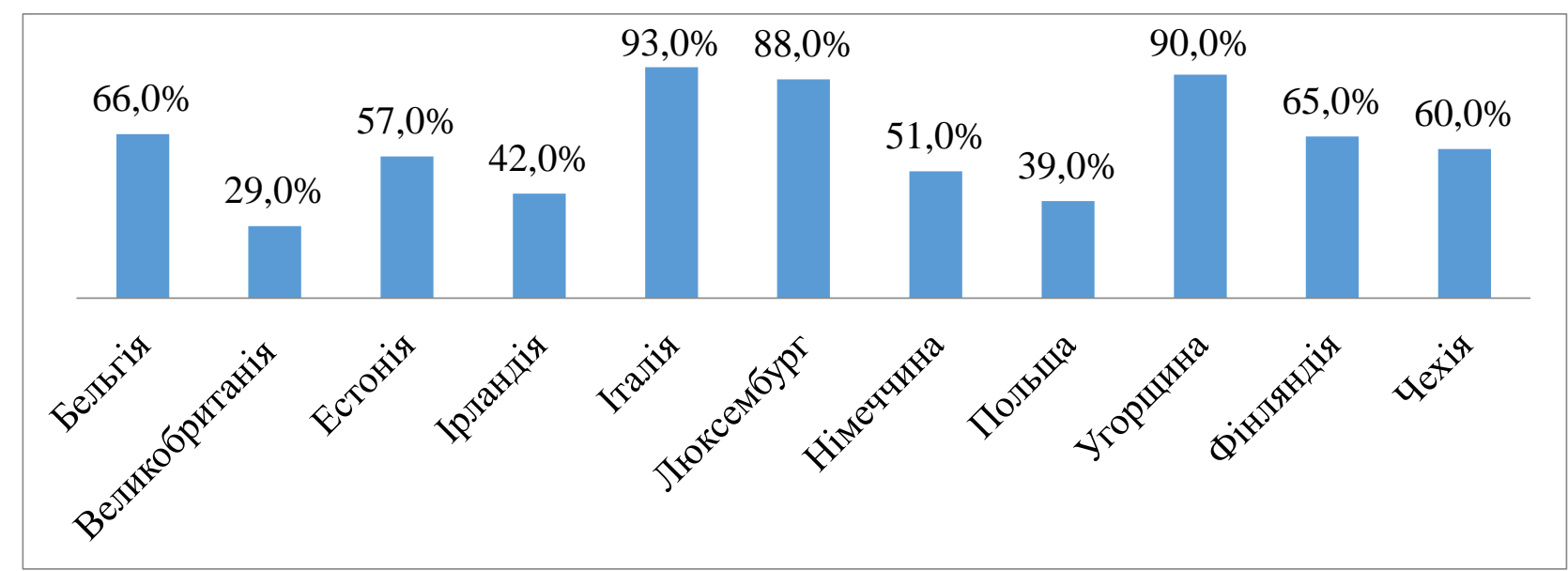

Рис. 2. Коефіцієнт заміщення серед країн ЄС у 2016 році

*Складено авторами за матеріалами [10]

Найнижче значення коефіцієнта заміщення спостерігається у Великобританії (яка є скоріше виключенням) - 29,0\%, що пояснюється багаторівневістю іiі пенсійних систем і саме недержавна пенсійна система користується найбільшою популярністю серед населення. Саме система даного типу дає змогу отримувати достатню пенсію, розмір якої працівник регулює самостійно, виходячи зі свої внесків. Спостерігається поступове витіснення приватним пенсійним забезпеченням державного [11]. В той час як середнє значення коефіцієнту за країнами ЄС складає 70,9\% і за рекомендацією МОП таке значення $\epsilon$ прийнятним. Проаналізована за даним показником національна пенсійна система України не $\epsilon$ адекватною (коефіцієнт складає - 27,88\% )[3], оскільки держава не в змозі на загальнодержавному рівні компенсувати втрачений працівником заробіток на мінімально необхідному рівні. На рис.3 зображено динаміку коефіцієнта заміщення, яка свідчить про перевищення темпів приросту заробітної плати над темпами зростання пенсій. 


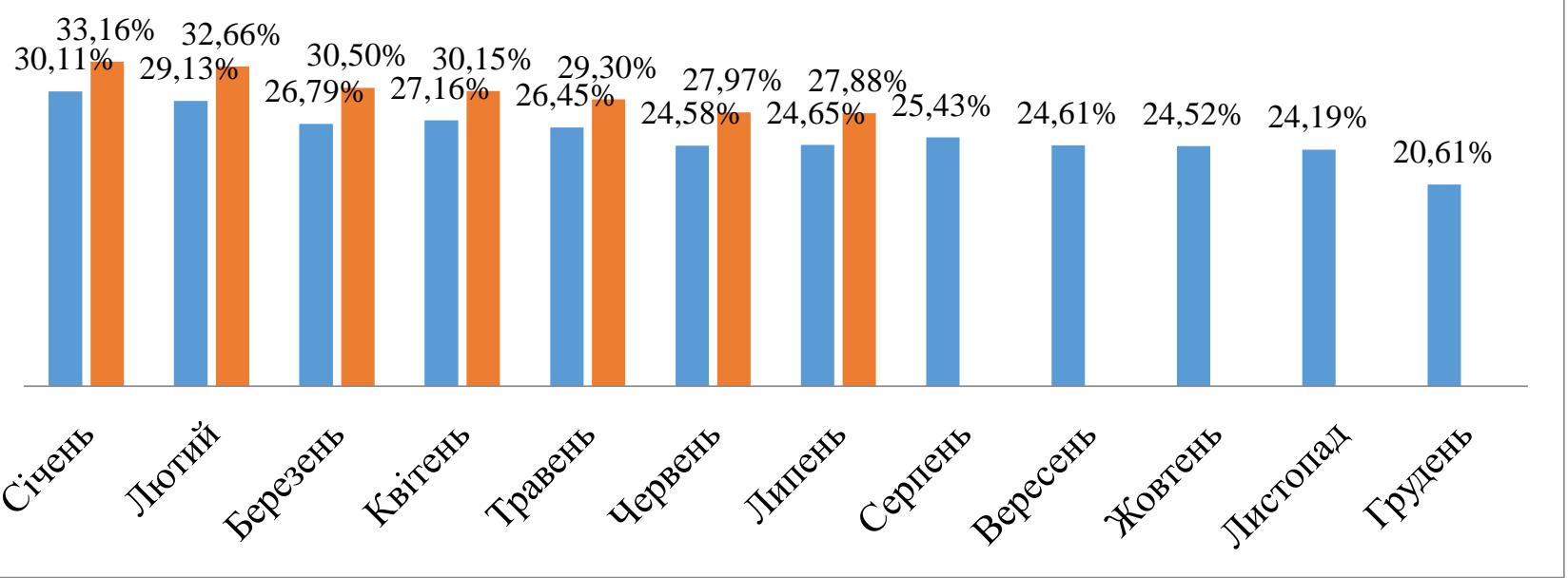

\section{Рис. 3. Динаміка коефіціснта заміщення у 2017 - 2018 роках* \\ *Складено авторами за матеріалами [3]}

Очікується, що за умов виконання кожною країною розроблених для неї рекомендацій загальні витрати $€ C$ на державні пенсії у відсотках від ВВП будуть на одному рівні, та пенсійні виплати будуть адекватними рівню життя.

Основою сучасної пенсійної системи України є запроваджене 3 січня 2004 року загальнообов'язкове державне пенсійне страхування, за якою має функціонувати пенсійна система трьох рівнів, з яких фактично діють лише два -солідарна система загальнообов'язкового пенсійного страхування та система добровільних пенсійних заощаджень, які акумулюються недержавними пенсійними фондами (без державної підтримки ) [12]. Очевидно, що солідарна система $\epsilon$ в цілому неефективною як у суто економічному аспекті (лягає непомірним тягарем на державний бюджет України), так і 3 погляду соціальної справедливості (недодержання страхових принципів - наявність значних пільг у пенсійному забезпеченні окремих категорій працівників при однаковому розмірі відрахувань; неадекватність пенсійного забезпечення). 32004 року в Україні планувалось запровадження другого рівня системи пенсійного забезпечення - накопичувальної системи загальнообов'язкового пенсійного страхування. Але до цього часу він не працює. Останнє реформування першого рівня пенсійної системи відбулося у жовтні 2017 року і закріплено у законопроекті №6614 "Проект Закону про внесення змін до деяких законодавчих актів України щодо підвищення пенсій", який спрямовано на поступове забезпечення пенсійної адекватності у довгостроковій перспективі. т Також 32019 року планується перерахунок пенсій за новою формулою, де розмір пенсій буде залежати від рівня інфляції та зарплати - «50\% інфляції $+50 \%$ від середнього зростання зарплат за три роки». На суму відсотку збільшиться розрахунковий розмір зарплати у формулі розрахунку пенсії, що дозволить підвищити коефіцієнт заміщення пенсією втраченого заробітку.

Виходячи 3 аналізу викладеного матеріалу, сучасна державна пенсійна система України не в змозі забезпечити своїм пенсіонерам достатній рівень соціального захисту, що зумовлено причинами об'єктивного характеру, які неможливо швидко усунути. Для подолання фінансової кризи пенсійної системи, уряд може обрати один 3 двох шляхів - раціоналізація існуючої системи ( усунення наслідків) або ж повна реструктуризація пенсійної системи (зміна правил на майбутнє, усунення причин) [11]. Цей шлях, на нашу думку, є єдиним щодо подолання кризи пенсійної системи України, тому що виходячи 3 міжнародного досвіду найвищий рівень соціального захисту пенсіонерів забезпечують ті країни, де окрім солідарної системи функціонують інші рівні накопичувальна система загальнообов'язкового державного пенсійного страхування та система недержавного пенсійного забезпечення.

Висновки i перспективи подальших досліджень. Питання зайнятості працездатного населення, стійкості і адекватності систем пенсійного забезпечення пов'язані між собою. Для того, щоб зберегти стійке співвідношення між стажем роботи і періодом отримання пенсійних виплат і надати право на отримання адекватної пенсії у суспільствах з регресивним типом відтворення країн ЄС збільшують вік 
виходу на пенсію. Така тенденція є актуальною і для України, що є на наш погляд недоречним, адже тривалість життя в Україні скорочується за наявних соціально-економічних умов (низький рівень життя, відсутність доступу до якісних медичних послуг). Одним 3 варіантів виходу із ситуаціі, що склалася, $\epsilon$ створення умов та стимулювання функціонування трирівневої пенсійної системи, яка на сьогоднішній день не працює в Україні. Проведені дослідження свідчать, що пенсійні системи 3 оптимальним співвідношенням між державною, професійною і приватною складовими можуть забезпечити стабільність та адекватність пенсійних систем. Запропонований вимірник адекватності пенсійної системи - коефіцієнт заміщення пенсією втраченого заробітку (прийнятний МОП на рівні 40\%) - сягає країнах ЄС у середньому $70 \%$, у той час як в Україні не наближується навіть до мінімально припустимого рівня $(27,88 \%)$. Незважаючи на існуючі рекомендації МОП щодо його використання при розрахунку пенсійних виплат, в Україні він демонструє один зі своїх найбільших недоліків - не враховує динаміку зростання середньої заробітної плати.
Оскільки за нинішніх соціальних і економічних умов держава не має змоги індексувати пенсійні виплати через брак бюджетних ресурсів, то пенсійні виплати відповідно не можуть бути адекватними потребам пенсіонерів. 3 цього випливає необхідність пошуку альтернативи забезпечення функціонування накопичувального рівня пенсійної системи.

Проаналізовано структуру індексу стійкості національних пенсійних систем і визначено фактори, що найбільше впливають на його зростання, такі як демографічна ситуація, дефіцит державного бюджету та структура пенсійної системи. В той час як досить складно впливати на перші два чинники, розбудова трирівневої пенсійної системи в України є реальним шляхом подолання кризи сучасної пенсійної системи. Узагальнено класифікацію показників оцінки стійкості пенсійних систем та показників вимірювання адекватності пенсій і виявлено, що пенсійні виплати в Україні не є адекватними забезпеченню потреб життєдіяльності пенсіонерів. Потребують подальшого дослідження альтернативні показники розрахунку адекватних пенсійних виплат

\section{ПЕРЕЛІК ВИКОРИСТАНИХ ДЖЕРЕЛ}

1. Роик В. Д. Социальная политика современной России [Електронний ресурс] / В.Д. Роик // Контуры глобальных трансформаций: политика, экономика, право. 2013. №2 (28). - Режим доступу: http://cyberleninka.ru/article/n/sotsialnaya-politika-sovremennoy-rossii.

2. Загорєєва О.Ю. Деякі аспекти балансування доходів та витрат пенсійного фонду [Електронний ресурс] / О.Ю. Загорєєва // «Економічні науки». Серія «Облік і фінанси». - Випуск 7 (25). Ч. 1. - 2010. - Режим доступу: http://nbuv.gov.ua/UJRN/ecnof_2010_7\%281\%29_63

3. Статистична інформація [Електронний ресурс] // Державна служба статистики України. - Режим доступу: www.ukrstat.gov.ua.

4. Population on 1 January by age and sex [Електронний ресурс] // Eurostat . - Режим доступу: http://appsso.eurostat.ec.europa.eu/nui/show.do?dataset=demo_pjan\&lang=en

5. European Union pension systems: Adequate and sustainable? [Електронний ресурс] // European Parliament . Режим доступу: http://www.europarl.europa.eu/thinktank/en/document.html?reference=EPRS_BRI(2015)571327

6. Хить Л. В. Комплексная оценка эффективности пенсионной системы как приоритетное направление социально-экономической политики России [Електронний ресурс] / Л. В. Хить // Теория и практика общественного развития. 2011. №2. - Режим доступу: http://cyberleninka.ru/article/n/kompleksnaya-otsenkaeffektivnosti-pensionnoy-sistemy-kak-prioritetnoe-napravlenie-sotsialno-ekonomicheskoy-politiki-rossii.

7. 2016 Pension Sustainability Index - Allianz - September 2016. [Електронний ресурс] // FIAP. - Режим доступу: https://fiapinternacional.org/en/2016-pension-sustainability-index-allianz-september-2016/

8. Holzmann R. An International Perspective on Pension Systems and Reform. [Електронний pecypc] / R. Holzmann, R. Hinz. - Режим доступу: https://doi.org/10.1596/0-8213-6040-X

9. Соловьев А.К. Коэффициент замещения трудовой пенсии: конфликт макроэкономических и социальных целей [Електронний ресурс]/ А.К. Соловьев // ЭНСР. 2014. №3 (66). - Режим доступу: http://cyberleninka.ru/article/n/koeffitsient-zamescheniya-trudovoy-pensii-konflikt-makroekonomicheskih-i-sotsialnyhtseley.

10. Net pension replacement rates [Електронний pecypc] // OECD Data. - Режим доступу: https://data.oecd.org/pension/net-pension-replacement-rates.htm

11. Філіпчук П.В. Системи пенсійного забезпечення: огляд світового досвіду [Електронний ресурс]/ П.В.Філіпчук/Національна академія державного управління при президентові України. 2010. - Режим доступу: http://www.academy.gov.ua/ej/ej10/doc_pdf/Filipchuk.pdf

12. Коротка характеристика пенсійної системи в Україні. [Електронний ресурс] // Головне управління Пенсійного фонду України в Черкаській області. - Режим доступу: http://ckpfu.gov.ua/?p=1228 


\section{REFERENCES}

1. Roik, V. D. (2013). Sotsialnaya politika sovremennoy Rossii [The social policy of modern Russia]. Konturyi globalnyih transformatsiy: politika, ekonomika, pravo, 2 (28), 6-31. Retrived from: http://cyberleninka.ru/article/n/sotsialnaya-politika-sovremennoy-rossii [in Russian].

2. Zahoryeyeva, O.Yu. (2010). Deyaki aspekty balansuvannya dokhodiv ta vytrat pensiynoho fondu [Some aspects of balancing income and expenditure of the pension fund]. Ekonomichni nauky: Oblik i finansy, 7 (25), 488-494. Retrived from: http://nbuv.gov.ua/UJRN/ecnof_2010_7\%281\%29_63 [in Ukrainian].

3. Derzhavna sluzhba statystyky Ukrainy [State Statistics Service of Ukraine]. Retrived from: www.ukrstat.gov.ua [in Ukrainian].

4. Population on 1 January by age and sex. Retrived from: http://appsso.eurostat.ec.europa.eu/nui/show.do?dataset=demo_pjan\&lang=en [in English].

5. European Union pension systems: Adequate and sustainable? (2015). Retrived from: http://www.europarl.europa.eu/thinktank/en/document.html?reference=EPRS_BRI [in English].

6. Khit', L. V. (2011). Kompleksnaya otsenka effektivnosti pensionnoy sistemy kak prioritetnoye napravleniye sotsial'no-ekonomicheskoy politiki Rossii [Integrated assessment of the efficiency of the pension system as a priority area of socio-economic policy in Russia]. Teoriya i praktika obshchestvennogo razvitiya, 2 . Retrived from: http://cyberleninka.ru/article/n/kompleksnaya-otsenka-effektivnosti-pensionnoy-sistemy-kak-prioritetnoe-napravleniesotsialno-ekonomicheskoy-politiki-rossii [in English].

7. Pension Sustainability Index - Allianz (2016). Retrived from: https://fiapinternacional.org/en/2016-pensionsustainability-index-allianz-september-2016/ [in English].

8. Holzmann, R. \& Hinz, R. (2005). An International Perspective on Pension Systems and Reform. Retrived from: https://doi.org/10.1596/0-8213-6040-X [in English].

9. Solov'yev, A.K. (2014). Koeffitsiyent zameshcheniya trudovoy pensii: konflikt makroekonomicheskikh i sotsial'nykh tseley. [Replacement rate of the retirement pension: the conflict of macroeconomic and social objectives]. ENSR, 3 (66). Retrived from: http://cyberleninka.ru/article/n/koeffitsient-zamescheniya-trudovoy-pensii-konfliktmakroekonomicheskih-i-sotsialnyh-tseley [in Russian].

10. Net pension replacement rates. Retrived from: https://data.oecd.org/pension/net-pension-replacement-rates.htm [in English].

11. Filipchuk, P.V. (2010). Systemy pensiynoho zabezpechennya: ohlyad svitovoho dosvidu. [Pension systems: A review of world experience]. Natsional'na akademiya derzhavnoho upravlinnya pry prezydentovi Ukrayiny. Retrived from: http://www.academy.gov.ua/ej/ej10/doc_pdf/Filipchuk.pdf [in Ukranian].

12. Korotka kharakterystyka pensiynoyi systemy v Ukrayini. [Brief description of the pension system in Ukraine]. Retrived from: http://ckpfu.gov.ua/?p=1228 [in Ukranian].

Одержано 15.09.2018 p. 